\title{
Refining the Canegro model for improved \\ simulation of climate change impacts on sugarcane
}

Jones, Matthew R. ${ }^{\text {a }}$; Singels, Abraham ${ }^{\text {b,c }}$

${ }^{\mathrm{a}, \mathrm{b}}$ South African Sugarcane Research Institute, Mount Edgecombe, South Africa

amatthew.jones@sugar.org.za

babraham.singels@sugar.org.za

${ }^{c}$ Department of Plant and Soil Sciences, University of Pretoria, Pretoria, South Africa

Corresponding author: Matthew Jones, matthew.jones@sugar.org.za. 


\begin{abstract}
Crop models can be used for predicting climate change impacts and exploring adaptation strategies, but their suitability for such tasks needs to be assessed. Although the DSSATCanegro model has been used widely for climate impact studies, some shortcomings have been revealed.
\end{abstract}

The objectives were to improve and evaluate the capability of DSSAT-Canegro to predict crop responses to climate change. Model changes included improved simulation of elevated temperature and atmospheric $\mathrm{CO}_{2}$ concentration ([CO2]) impacts, and revised algorithms for tillering, respiration and crop water relations.

After calibration, the refined model was tested against an independent set of experimental data, demonstrating acceptable simulation accuracy for aerial dry mass, stalk dry mass and stalk sucrose mass $(\mathrm{RMSE}=8.4,5.2$ and $3.3 \mathrm{t} / \mathrm{ha}$ respectively). A multiple-site sensitivity analysis revealed that simulated responses by the refined model, of canopy formation, crop water use, crop water status and stalk dry mass to changes in rainfall, temperature and [CO2], were more realistic than those of the old model. Highest average simulated stalk mass was achieved at a temperature regime that was $3{ }^{\circ} \mathrm{C}$ warmer than current climate, with yield increases ranging from $0.7 \%$ (irrigated Ligne Paradis, Reunion Island) to $7 \%$ (rainfed Piracicaba, Brazil). Elevated [CO2] increased yields for rainfed production only (7\% for La Mercy, South Africa and $6 \%$ for Piracicaba, $[\mathrm{CO} 2]=750 \mathrm{ppm})$, through reduced transpiration and improved crop water status.

The study highlighted the need for improvements in simulating reduced growth of older crops, and [CO2] effects on transpiration. This study has delivered an improved Canegro model that represents plant processes and their interactions with climatic drivers more 
realistically, and can predict crop growth, water use and yields, for a wide range of climates, reasonably accurately. We propose that this revised Canegro model is included in a forthcoming release of the DSSAT Cropping System Model, for use in climate change impact studies.

\section{Highlights}

- The refined DSSAT-Canegro predicts stalk dry mass to within 6 t/ha

- The refined DSSAT-Canegro has improved capability for simulating climate change impacts.

- Model changes address temperature responses, water relations, respiration, tillering.

- Multi-site sensitivity analysis shows plausible responses to climate change factors.

Keywords: Canegro, climate change, sugarcane, temperature, respiration, evapotranspiration, carbon dioxide.

\section{INTRODUCTION}

Sugarcane (complex hybrid of Saccharum spp.) is an important crop grown in tropical and subtropical regions in over 100 countries. Globally, 1.9 billion tons of cane were produced in 2013 from 27 million ha $(\mathrm{FAO}, 2016)$. The most important products from sugarcane are sugar, an important component of the human diet, and renewable energy in the form of bioethanol and electricity. Future climate change is expected to have important consequences for sugarcane production, and reliable predictions of crop response to climate change are necessary to plan adaptation strategies. Crop simulation models can be used in conjunction with global climate models to predict the likely crop responses to changed climate for 
different production management strategies. Climate change studies require that models simulate crop growth under climatic conditions that are vastly different to that experienced in past field experiments used for model development. The capability of sugarcane models to do this needs to be assessed and understood.

The study by Singels et al. (2014) contains a brief review of climate change impact studies on sugarcane up to 2013. Since then, studies have been conducted by Biggs et al. (2013), Marin et al. (2013), Jones et al. (2015), de Carvalho et al. (2015) and Everingham et al. (2015). Biggs et al. (2013) used the APSIM-Sugar model (Keating et al., 1999) to explore the impact of expected climate change in the near future (around 2030) on sugarcane yields and nitrogen losses under different management systems in Australia. The study found that yield response to climate change depended strongly on the assumed $\mathrm{CO}_{2}$ fertilisation effect. Marin et al. (2013) analysed the sensitivity of crop responses simulated by the DSSAT-Canegro model (Singels et al., 2008; Singels and Bezuidenhout, 2002; Inman-Bamber, 1991) to changes in rainfall, temperature and [CO2] for Brazil and concluded that the uncertainty with regard to the $\mathrm{CO}_{2}$ fertilization effect remained a serious knowledge gap.

Jones et al. (2015), in a study to determine impacts on irrigated sugarcane in South Africa, confirmed the shortcomings in the DSSAT-Canegro model identified by Singels et al. (2014). Simulation of high-temperature effects on phenology, photosynthesis and respiration are based on extrapolation of relationships derived from research conducted at present-day temperature and vapour pressure deficit (VPD) regimes. The simulation of elevated [CO2] impacts on photosynthesis are based on a function developed for maize (Boote et al., 2010), whereby photosynthetic radiation conversion efficiency increases slightly with increasing [CO2] to reach about $104 \%$ at $735 \mathrm{ppm}$ of its value at the reference of $360 \mathrm{ppm}$. Available knowledge regarding sugarcane response to elevated [CO2] has been advanced in recent work (Stokes et al., 2016; Inman-Bamber et al., 2016) and should be considered together 
with information generated in earlier research (Vu et al., 2006; de Souza et al., 2008; Allen et al., 2011).

Furthermore, the simulation of water stress impacts on water use and biomass accumulation has been identified as too abrupt (Singels et al., 2010). Canegro (and APSIM-Sugar) uses the CERES (Jones and Kiniry, 1986) approach of calculating a "soil water deficit factor" (a measure of crop water status) to regulate supply limited water uptake and rate of photosynthesis. A study by Singels et al., 2010) showed that during the development of a stress event, simulated crop water status remained favourable for too long, and then declined too rapidly, compared with observations. The study also showed that simpler water uptake models that relate the onset of water stress to soil water thresholds that depend on evaporative demand performed as well as more complex models (Singels et al., 2010) and may require less calibration.

Another weakness of the DSSAT-Canegro model is the very empirical nature of the tillering algorithm, making it extremely difficult to calibrate the model for accurate simulation of the crop canopy, a key driver for water use and radiation capture. Although the algorithm accounts for row spacing and water stress, it does not simulate feedback processes. APSIMSugar also uses an empirical approach to mimicking the impacts of tiller production and senescence on the crop canopy (Keating et al., 1999).

Singels et al. (2014) also highlighted the need to rethink the simulation of respiration in the DSSAT-Canegro model. The study found that simulated crop growth stagnated for large crops (dry biomass of about 75 t/ha) grown in hot environments. Growth respiration (Thornley, 1976) was calculated as a constant fraction of gross photosynthate, while daily maintenance respiration $\left(R_{m}\right)$ was calculated as fraction of total dry biomass that depends on air temperature. The $R_{m}$ fraction increases exponentially with temperature with no upper 
limit (Singels et al., 2005a), based on the findings of Liu and Bull (2001). This was a refinement of the approach previously used in the Canegro model, which estimated $R_{m}$ as a fixed fraction of total dry biomass (Inman-Bamber, 1991). This does not adequately reflect current knowledge (Amthor, 2000; Gifford, 2003, Thornley, 2011). Everingham et al. (2015) highlighted the uncertainty regarding maintenance respiration when they considered two options for simulating maintenance respiration (zero and $0.4 \%$ of dry biomass per day) in their study to assess climate change impacts for sugarcane production in Australia. The zeromaintenance respiration approach is used in APSIM-Sugar.

The overall goal of this work was to improve and evaluate the DSSAT-Canegro model's capability to predict climate change impacts on crop development, growth and yield. The specific objectives were:

- to refine relevant algorithms in the Canegro model, by using recent research findings and modelling advances;

- to evaluate the model refinements, by comparing yield predictions from the two model versions with observed values from published experiments;

- to assess the refined model for application in climate change impact studies, by

- analysing the sensitivity of simulated canopy development, crop water relations and crop yield, to hypothetical climate change scenarios, at selected sites across the world; and

- comparing and analysing crop responses simulated by the two model versions, for the aforementioned climate change scenarios, at one irrigated and one rainfed site.

This work is part of a broader study that aims to assess the likely impacts of climate change, and to explore climate change adaptations, for sugarcane production in South Africa. The 
scope of this paper is, however, limited to describing improvements made to the DSSATCanegro model, and evaluating its suitability for climate change impact studies worldwide.

\section{MODEL DESCRIPTION}

The baseline version of the DSSAT-Canegro model used in this study is the version that was used by Singels et al. (2014) and is named V4.5_C1.1 (released as part of DSSAT V4.5 in 2012). It is derived from V4.5_C1.0, which is the version contained in the first release of Canegro in the DSSAT V4.5 package (Singels et al., 2008), but with the [CO2] impacts on transpiration and photosynthesis as described by Singels et al. (2014) included. The two refined model versions produced and evaluated in this study are named V4.5_C2.2 (with maintenance respiration simulated) and V4.5_C2.2_Rm0 (without maintenance respiration). The concepts and mathematical equations for changes brought about in V4.5_C1.1 to build V4.5_C2.2 and V4.5_C2.2_Rm0 are described in Appendix A, and cover the following aspects:

- The calculation of thermal time, a primary driver of phenological development, canopy formation and growth, was amended to include the limiting effect of very high temperatures.

- The descriptive, empirical tillering model was replaced with a simpler, more dynamic algorithm that accounts for temperature, water deficit stress, bud population and the shading effect of the developing canopy.

- The simulation of photosynthesis was adapted to reflect a wider optimal temperature range, while maintenance respiration is now only calculated for green living tissue and the cycling of stored sucrose in the stalk, instead of for total biomass. 
- The CERES approach of simulating water deficit stress (Jones \& Kiniry, 1986) was replaced with the simpler AquaCrop (Steduto et al., 2009) algorithm that uses soil water depletion thresholds which vary with atmospheric evaporative demand, to enable a more gradual transition from well-watered to water-stressed states.

- Minor amendments were made to the root aeration stress routine.

Simulation of [CO2] on photosynthesis and transpiration are also described for the record (Appendix A). Acronyms used in the rest of paper are listed in Appendix B.

\section{METHODS}

\subsection{Model calibration and validation}

\subsubsection{Datasets and statistical parameters}

The experimental datasets used in Singels and Bezuidenhout (2002), summarised in Table 1, were used for model calibration and validation. Data were selected for calibration and validation by randomly assigning datasets (a dataset is the data collected for a given treatment in a given experiment) with aerial dry biomass (ADM, t/ha) observations into two equal-sized (six sets each) classes: one for validation (31 data points) and one for calibration (35 data points). All datasets that did not have ADM observations, but did include SDM observations (12 sets, with 72 data points), were included in the validation set.

Statistical parameters that were used to quantify the accuracy of ADM, SDM and stalk sucrose mass (SUCM, t/ha) simulations were:

- the coefficient of determination $\left(\mathrm{R}^{2}\right)$, 
Table 1. Experimental details of the model calibration and validation data sets.

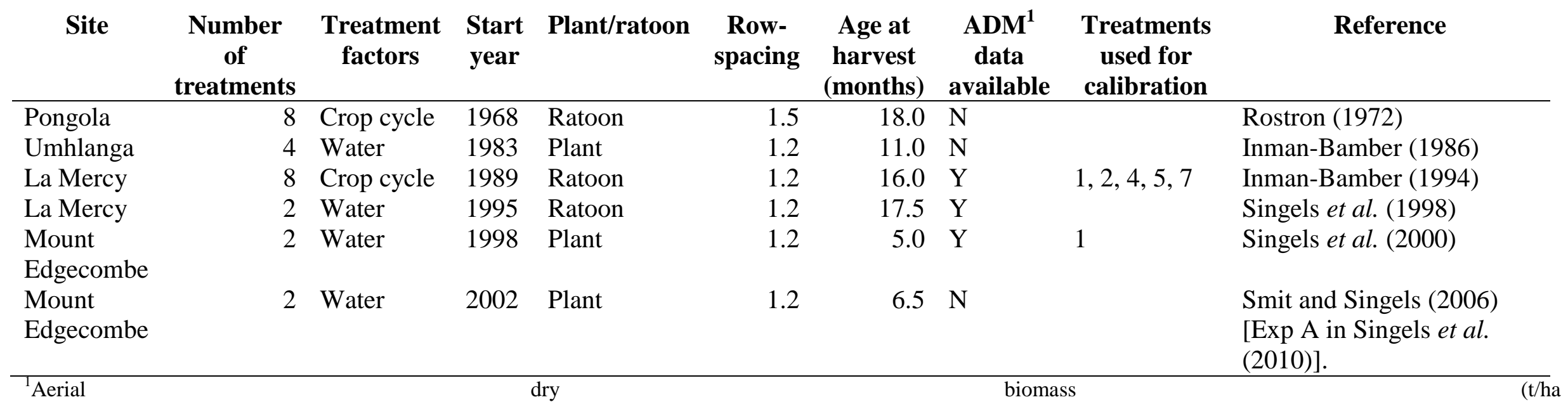


- the slope and intercept of the linear regression between simulated and observed values,

- root mean squared error (RMSE, defined as the square root of the mean squared difference between simulated and observed values), and

- the average prediction error (APE, defined as the average difference between simulated and observed values).

\subsubsection{Model calibration}

The objectives of the model calibration were (a) to determine appropriate values for the MaxPARCE parameter for two versions of the refined model, V4.5_C2.2 and V4.5_C2.2_Rm0, and (b) to determine an appropriate STKPFMAX value for both model versions. All other parameter values were taken from published data as explained in the model description (see Table 2).

For the V4.5_C2.2 calibration, optimal values for cultivar parameters MaxPARCE and STKPFMAX were estimated for selected datasets described in Table 1. ADM data were used to determine the value for MaxPARCE, and then stalk dry mass (SDM, t/ha) data were used to determine the value for STKPFMAX. Parameter values were determined by trial and error, with the objective of minimising differences between simulated and observed values by: minimising APE, RMSE and intercept of linear regression; maximising $\mathrm{R}^{2}$; and attempting to find a slope of linear regression close to 1.0 .

The calibration of MaxPARCE for V4.5_C2.2_Rm0 followed a similar method, but used all the datasets with ADM data listed in Table 1. 
Table 2. Cultivar trait parameter values for cultivar NCo376 for the DSSAT-Canegro V4.5_C2.2 and V4.5_C2.2_Rm0 models, compared to values used for V4.5_C1.1.

\begin{tabular}{|c|c|c|c|}
\hline Parameter & Description & V4.5_C1.1 & $\begin{array}{l}\text { V4.5_C2.2, } \\
\text { V4.5_C2.2_Rm0 }\end{array}$ \\
\hline MaxPARCE & $\begin{array}{l}\text { Maximum (no stress) radiation } \\
\text { conversion efficiency expressed } \\
\text { as assimilate produced before } \\
\text { respiration, per unit PAR (g/MJ) }\end{array}$ & 9.9 & Calibrated \\
\hline APFMX & $\begin{array}{l}\text { Maximum fraction of dry mass } \\
\text { increments that can be allocated } \\
\text { to aerial dry mass }(t / t)\end{array}$ & 0.88 & 0.88 \\
\hline STKPFMAX & $\begin{array}{l}\text { Fraction of daily aerial dry mass } \\
\text { increments partitioned to stalk at } \\
\text { high temperatures in a mature } \\
\text { crop (t/t on a dry mass basis) }\end{array}$ & 0.65 & Calibrated \\
\hline SUCA & $\begin{array}{l}\text { Sucrose partitioning parameter: } \\
\text { maximum sucrose contents in the } \\
\text { base of stalk }(\mathrm{t} / \mathrm{t})\end{array}$ & 0.58 & 0.58 \\
\hline $\mathrm{dPERdt}^{1}$ & $\begin{array}{l}\text { Change in plant extension rate per } \\
\text { unit change in effective } \\
\text { temperature }\left(\mathrm{mm} / \mathrm{h} /{ }^{\circ} \mathrm{C}\right)\end{array}$ & 0.176 & \\
\hline $\mathrm{SER}_{0}{ }^{1}$ & $\begin{array}{l}\text { Change in stalk extension rate per } \\
\text { unit change in effective } \\
\text { temperature }\left(\mathrm{mm} / \mathrm{h} /{ }^{\circ} \mathrm{C}\right)\end{array}$ & & 0.14 \\
\hline $\mathrm{LER}_{0}{ }^{1}$ & $\begin{array}{l}\text { Change in leaf extension rate per } \\
\text { unit change in effective } \\
\text { temperature }\left(\mathrm{mm} / \mathrm{h} /{ }^{\circ} \mathrm{C}\right)\end{array}$ & & 0.176 \\
\hline LFMAX & $\begin{array}{l}\text { Maximum number of green } \\
\text { leaves a healthy, adequately- } \\
\text { watered plant will have after it is } \\
\text { old enough to lose some leaves }\end{array}$ & 12 & 12 \\
\hline MXLFAREA & $\begin{array}{l}\text { Max leaf area assigned to all } \\
\text { leaves above leaf number } \\
\text { MXLFARNO }\left(\mathrm{cm}^{2}\right)\end{array}$ & 360 & 360 \\
\hline MXLFARNO & $\begin{array}{l}\text { Leaf number above which leaf } \\
\text { area is limited to MXLFAREA }\end{array}$ & 15 & 15 \\
\hline PI1 & $\begin{array}{l}\text { Phyllocron interval } 1 \text { (for leaf } \\
\text { numbers below Pswitch, }{ }^{\circ} \mathrm{C} \mathrm{d}\end{array}$ & 69 & 69 \\
\hline PI2 & $\begin{array}{l}\text { Phyllocron interval } 2 \text { (for leaf } \\
\text { numbers above Pswitch, }{ }^{\circ} \mathrm{C} \mathrm{d}\end{array}$ & 169 & 169 \\
\hline PSWITCH & $\begin{array}{l}\text { Leaf number at which the } \\
\text { phyllocron changes. }\end{array}$ & 18 & 18 \\
\hline TTPLNTEM & $\begin{array}{l}\text { Thermal time to emergence for a } \\
\text { plant crop }\left({ }^{\circ} \mathrm{C} \mathrm{d}\right)\end{array}$ & 428 & 150 \\
\hline TTRATNEM & $\begin{array}{l}\text { Thermal time to emergence for a } \\
\text { ratoon crop }\left({ }^{\circ} \mathrm{C} \mathrm{d}\right)\end{array}$ & 203 & 100 \\
\hline CHUPIBASE & $\begin{array}{l}\text { Thermal time from emergence to } \\
\text { start of stalk growth }\left({ }^{\circ} \mathrm{C} \text { d }\right)\end{array}$ & 1050 & 1050 \\
\hline
\end{tabular}


The number of lower order tillers produced per higher order tiller per unit thermal time $\left(/{ }^{\circ} \mathrm{C} \mathrm{d}\right)$ for unstressed crops

POPCF(1) Quadratic coefficient for quadratic tillering equation

POPCF(2) Linear coefficient for quadratic tillering equation

TT_POPGROWTH Thermal time from emergence to

MAX_POP peak tiller population $\left({ }^{\circ} \mathrm{C} \mathrm{d}\right)$ Maximum tiller population

POPTT16 (stalks $/ \mathrm{m}^{2}$ )

Stalk population at/after

$\mathrm{PUP}_{5, \mathrm{PT}}$

Drought sensitivity coefficient:

The soil water depletion fraction

below which transpiration and

photosynthesis rates are reduced

at the reference atmospheric

evaporative demand of $5 \mathrm{~mm} / \mathrm{d}$

\footnotetext{
${ }^{1}$ The ecotype parameter $d P E R d T$ is used in V4.5_C1.1 to drive leaf and stalk elongation, as a function of thermal time. In the V4.5_C2.2 and V4.5_C2.2_Rm0 model versions, this parameter is separated into two distinct cultivar parameters LERO (driving leaf elongation) and SERO (driving stalk elongation), with independently-calculated thermal time accumulation using corresponding cardinal temperature parameters.
} 
Species and ecotype parameter values not specified in Table 2 or in the model description text (Appendix A, Sections A1 to A4) were the same as listed in Singels et al. (2008).

\subsubsection{Model validation}

Two model validation exercises were performed. The first was to evaluate the V4.5_C2.2 model's performance, using the independent validation datasets. The second exercise compared model performance of the two calibrated versions of the refined model (V4.5_C2.2 and V4.5_C2.2_Rm0) with that of the V4.5_C1.1 model (using published model parameters), for all datasets listed in Table 1 (the calibration and validation sets combined); this was for consistency with previous publications (Singels and Bezuidenhout, 2002; Singels et al., 2008).

\subsection{Climate change sensitivity analysis methods}

The following factor changes were investigated, following AgMIP protocols (Rosenzweig et al., 2013):

- Temperature: $-3,0,+3,+6,+9{ }^{\circ} \mathrm{C}$ difference from baseline daily values

- Rainfall: $-25,-10,0,+10,+25 \%$ relative to baseline daily values

- [CO2]: $360,450,550,650,750 \mathrm{ppm}$

Each treatment was implemented by applying a single weather data transformation to daily values of the observed historical weather data series, to create a 'climate changed' weather data scenario. These transformations were: addition of a temperature offset; multiplication by a relative rainfall amount; and specification of a [CO2] value. Climate sensitivity impacts were calculated by expressing the difference between the simulated outputs of each climate 
changed scenario with the simulation outputs for the baseline climate scenario, as percentages of the baseline values.

Six sites were selected for the climate change sensitivity analysis based on those used in an AgMIP Sugarcane model inter-comparison study (Jones et al., 2014). Two sites from the AgMIP set were omitted: Houma (USA), because the weather data were not available; and San Carlos (Ecuador), because the volumetric soil water-holding capacities calculated from soil texture by the DSSAT SBuild tool appeared too high to be realistic. The baseline climate for each of the sites is shown in Figure 1. Soil profiles were chosen to represent typical soils at each site, as specified in the AgMIP study. This is more realistic than using an identical soil for each site.

Irrigation strategies and crop start and harvest dates were made consistent across sites to reduce confounding due to management and seasonal differences. The differential responses to climate change sensitivity treatments could therefore be primarily attributed to weather and soil differences at the between the sites. All sites were simulated using the V4.5_C2.2 model as 12-month ratoon crops starting on 15 October each year, and as many crops were simulated as permitted by the length of the weather data records at each site (Table 3 ). The two South African sites were additionally simulated with a 1 October and 1 April start dates, in order to explore seasonal differences. All irrigated sites were irrigated according to a strategy whereby $32 \mathrm{~mm}$ of irrigation was applied via overhead sprinkler when the total soil profile plant-available water-holding capacity depleted by $32 \mathrm{~mm}$. The irrigation settings were chosen to minimise the occurrence of water deficit stress.

Initial soil water content was set to $50 \%$ of plant-available capacity $\left(\mathrm{PAWC}, \mathrm{cm}^{3} / \mathrm{cm}^{3}\right.$ ) for each dryland crop and to $100 \%$ of PAWC for each irrigated crop. Sugarcane is usually 'dried-off' before harvest (i.e. irrigation is withheld a few weeks before harvest, to increase 
stalk sucrose content). The DSSAT CSM does not, however, make provision for the automatic cessation of irrigation towards the end of the growing period. As a result, irrigation requirements might have been overestimated. Initializing simulations with $100 \%$ PAWC reduced the irrigation requirement at start of the crop. The intention was that this saving would offset the additional water applied unrealistically prior to harvest - resulting in more accurate seasonal irrigation water requirement calculations.

Long-term mean FiPAR, cumulative irrigation applied (mm), cumulative evapotranspiration $(\mathrm{ET}, \mathrm{mm})$, stalk dry mass at harvest $\left(\mathrm{SDM}_{\mathrm{H}}\right.$, t/ha), apparent whole-crop radiation use efficiency $\left(\mathrm{RUE}_{\mathrm{A}}, \mathrm{g} / \mathrm{MJ}\right)$ and apparent whole-crop transpiration efficiency $\left(\mathrm{TE}_{\mathrm{A}}, \mathrm{g} / \mathrm{kg}\right)$ were calculated for each site and climate change sensitivity treatment. RUE $\mathrm{A}_{\mathrm{A}}$ was calculated by dividing aerial dry biomass at harvest $\left(\mathrm{ADM}_{\mathrm{H}}\right.$, $\left.\mathrm{t} / \mathrm{ha}\right)$ by total intercepted shortwave radiation (not to be confused with maximum RUE, an input parameter in some crop models), and $\mathrm{TE}_{\mathrm{A}}$ was calculated by dividing $\mathrm{ADM}_{\mathrm{H}}$ by seasonal total transpiration.

Model settings for crop and soil parameters for each site are shown in Table 3.

\section{RESULTS}

\subsection{Model calibration and validation}

Performance of the different model versions in predicting ADM, SDM and SUCM for the crops listed in Table 1 is summarised in Table 4. 
La Mercy, South Africa

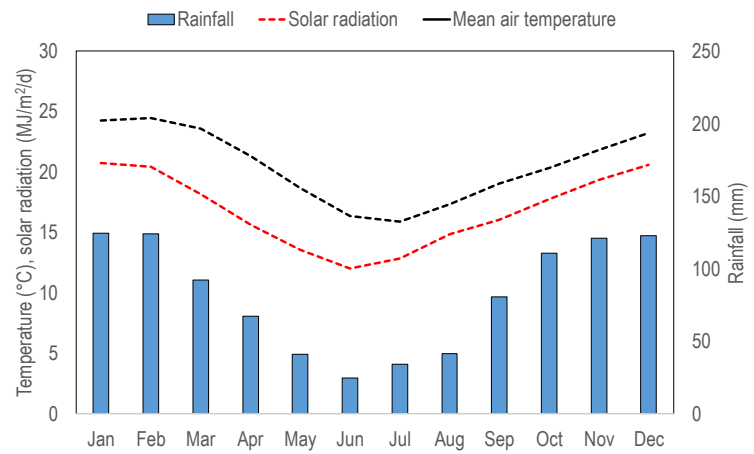

Ayr, Australia

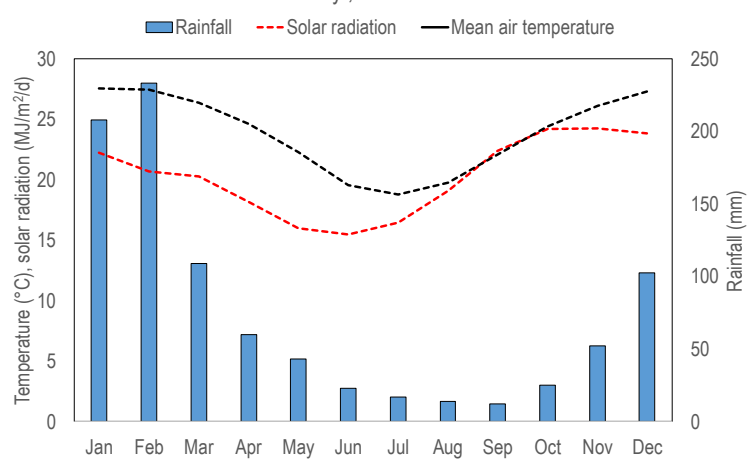

Ligne Paradis, Reunion Island

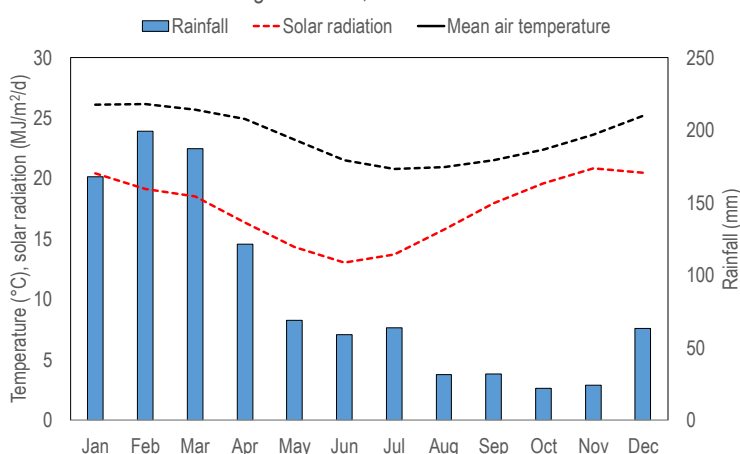

Komatipoort, South Africa

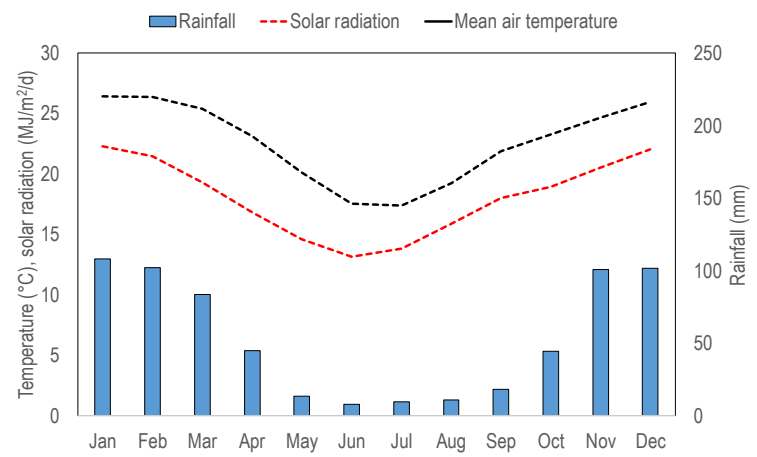

Piracicaba, Brazil

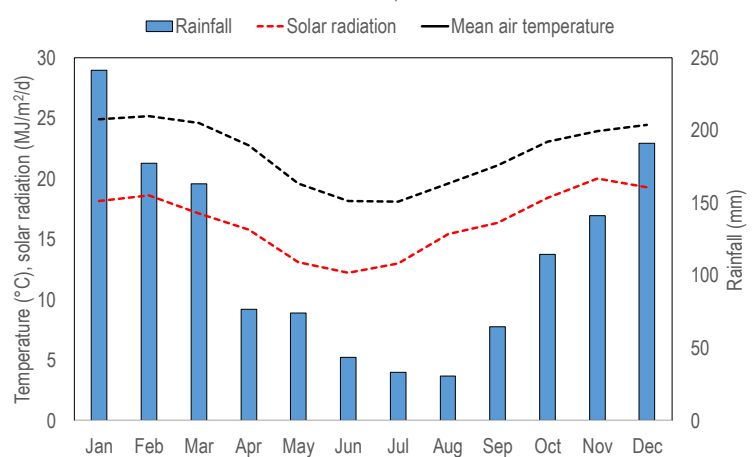

Chiredzi, Zimbabwe

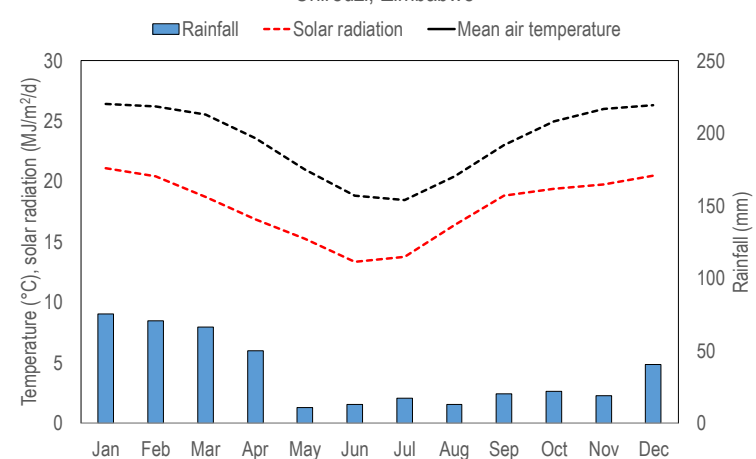

Figure 1. Long-term mean monthly rainfall, daily solar radiation and daily mean air temperature for the sites used for the climate change sensitivity analysis. 
Table 3. Sites and baseline model configuration for the climate change sensitivity analysis.

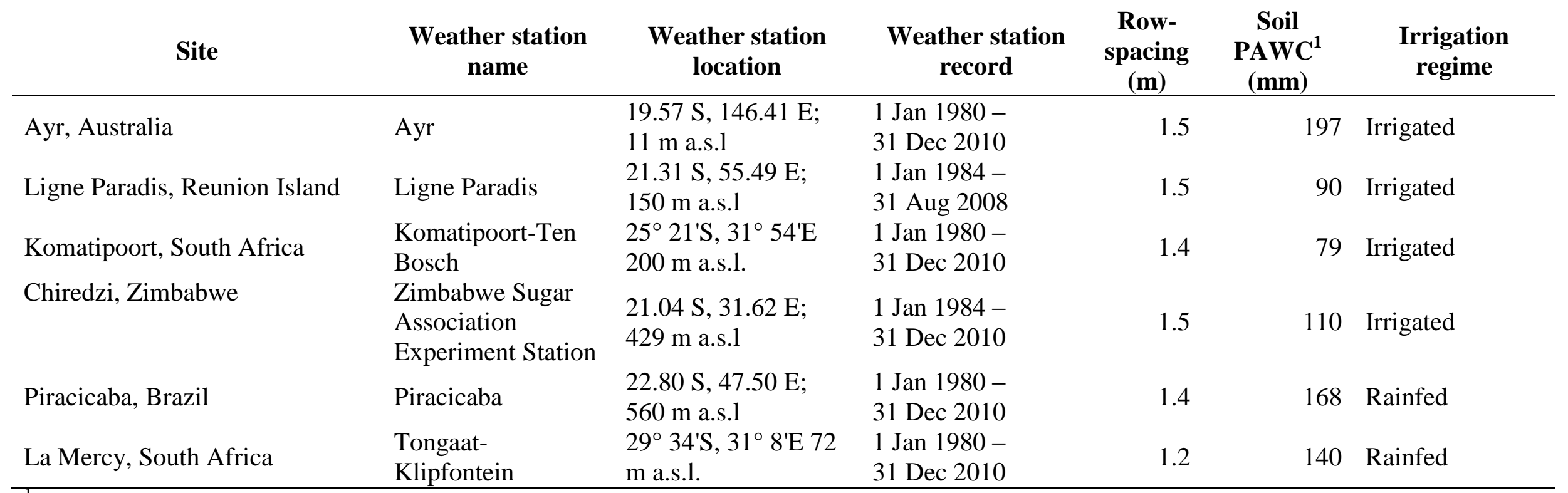

${ }^{1}$-Plant available water holding capacity 
The best model performance was achieved for MaxPARCE $=5.4 \mathrm{~g} / \mathrm{MJ}$ and STPFMAX $=0.75$. The best performance for V4.5_C2.2_Rm0 was achieved when MaxPARCE was set to $4.7 \mathrm{~g} / \mathrm{MJ}$.

The V4.5_C2.2 model version produced similar validation statistics ( $\mathrm{R}^{2}$ and RMSE) to those of version V4.5_C1.1, but with a more favourable slope and intercept for ADM predictions, and a smaller bias for SDM predictions. Sucrose yield predictions of the V4.5_C2.2 version were slightly less accurate than that of the V4.5_C1.1 version. Both model versions tended to underestimate high values of SDM and SUCM. V4.5_C2.2 prediction performance for green leaf area index has not been evaluated. A better test of the models' ability to predict intercepted radiation requires sequential FiPAR observations from diverse experiments.

Calibration and validation graphs are provided in Appendix C.

The introduction of zero maintenance respiration brought about a slight improvement in model predictions of SDM, with more accurate prediction of very high values. However, the accuracy of ADM predictions was not greater than that of the base version. We therefore conclude that the maintenance respiration algorithm should be included in Canegro (Table 4).

It is also concluded that the V4.5_C2.2 version of the model is sufficiently accurate for simulating ADM, SDM and SUCM yields for a diverse range of environments.

\subsection{Climate change sensitivity analysis results}

Results are presented and discussed for all sites (crop cycles starting in October), and in more detail for the South African sites (crop cycles starting in April and October). 
Table 4. Simulation accuracy following calibration of the DSSAT-Canegro V4.5_C2.2 (with maintenance respiration enabled) and V4.5_C2.2_RmO (with maintenance respiration disabled) models. ( $R^{2}$ is the coefficient of variation, $b$ and a are the slope and intercept of the linear regression between simulated $(S)$ and observed $(O)$ values, APE is the average prediction error defined as the average $S-O, R M S E$ is the root mean square error defined as the square root of the mean $(S-O)^{2}$, and $R M S E \%$ is $R M S E$ expressed as a percentage of the average $O$.

\begin{tabular}{|c|c|c|c|c|c|c|c|}
\hline Variable & $\mathbf{R}^{2}$ & b & b & APE & RMSE & RMSE\% & n obs. \\
\hline \multicolumn{8}{|c|}{ V4.5_C2.2, calibration data subset } \\
\hline $\begin{array}{l}\text { Aerial dry mass } \\
\text { (t/ha) }\end{array}$ & 0.88 & 0.98 & 1.41 & 0.81 & 5.46 & 16.05 & 35 \\
\hline $\begin{array}{l}\text { Stalk dry mass } \\
(\mathrm{t} / \mathrm{ha})\end{array}$ & 0.88 & 0.97 & 1.54 & 0.17 & 5.21 & 20.67 & 35 \\
\hline \multicolumn{8}{|c|}{ V4.5_C2.2_Rm0, calibration data subset } \\
\hline Aerial dry mass & 0.84 & 1.07 & -2.50 & 0.08 & 7.19 & 20.70 & 66 \\
\hline \multicolumn{8}{|c|}{ V4.5_C2.2, independent validation data subset } \\
\hline $\begin{array}{l}\text { Aerial dry mass } \\
(\mathrm{t} / \mathrm{ha})\end{array}$ & 0.80 & 1.06 & -2.05 & -0.06 & 8.36 & 23.46 & 31 \\
\hline $\begin{array}{l}\text { Stalk dry mass } \\
(\mathrm{t} / \mathrm{ha})\end{array}$ & 0.86 & 0.84 & 4.33 & 0.17 & 5.21 & 20.67 & 103 \\
\hline Sucrose mass (t/ha) & 0.82 & 0.88 & 2.31 & 0.90 & 3.25 & 28.27 & 104 \\
\hline \multicolumn{8}{|c|}{ V4.5_C1.1, all data } \\
\hline $\begin{array}{l}\text { Aerial dry mass } \\
(\mathrm{t} / \mathrm{ha})\end{array}$ & 0.83 & 0.75 & 9.59 & -0.95 & 6.57 & 18.64 & 66 \\
\hline $\begin{array}{l}\text { Stalk dry mass } \\
(\mathrm{t} / \mathrm{ha})\end{array}$ & 0.84 & 0.86 & 1.69 & 1.74 & 5.58 & 24.10 & 134 \\
\hline Sucrose mass (t/ha) & 0.81 & 0.88 & 1.07 & 0.23 & 3.14 & 29.58 & 135 \\
\hline \multicolumn{8}{|c|}{ V4.5_C2.2, all data } \\
\hline $\begin{array}{l}\text { Aerial dry mass } \\
(\mathrm{t} / \mathrm{ha})\end{array}$ & 0.84 & 1.02 & -0.18 & -0.40 & 6.97 & 19.95 & 66 \\
\hline $\begin{array}{l}\text { Stalk dry mass } \\
(\mathrm{t} / \mathrm{ha})\end{array}$ & 0.81 & 0.87 & 3.69 & -0.60 & 5.92 & 24.34 & 134 \\
\hline Sucrose mass $(\mathrm{t} / \mathrm{ha})$ & 0.78 & 0.90 & 2.27 & -1.16 & 3.65 & 32.25 & 135 \\
\hline \multicolumn{8}{|c|}{ 4.5_C2.2_Rm0, all data } \\
\hline $\begin{array}{l}\text { Aerial dry mass } \\
(\mathrm{t} / \mathrm{ha})\end{array}$ & 0.84 & 1.07 & $-\overline{2.50}$ & 0.08 & 7.19 & 20.70 & 66 \\
\hline $\begin{array}{l}\text { Stalk dry mass } \\
(\mathrm{t} / \mathrm{ha})\end{array}$ & 0.86 & 1.03 & 1.34 & -1.96 & 5.78 & 23.12 & 134 \\
\hline Sucrose mass (t/ha) & 0.83 & 1.07 & 1.31 & -2.02 & 3.98 & 33.85 & 135 \\
\hline
\end{tabular}




\subsubsection{Analysis of results for all sites}

Results are summarised in Tables 5 (irrigated sites) and 6 (rainfed sites).

A decrease in temperature caused a decrease in average SDM at all irrigated sites, with the biggest decline noted for Komatipoort (-18.1\%), followed by Chiredzi and Ligne Paradis (about $-14 \%$ ) and lastly Ayr (-8.7\%) (Table 5). These declines were caused by (1) decreases in FiPAR ranging from $-7.6 \%$ at Ligne Paradis to $-4.8 \%$ at Chiredzi, and (2) decreases in $\mathrm{RUE}_{\mathrm{A}}$ in the range $2.4-8.1 \%$. Highest average SDM was achieved at the $+3{ }^{\circ} \mathrm{C}$ temperature regime at all sites, with the highest increase from the baseline regime simulated for Komatipoort (4.6\%). Average SDM declined below that of the baseline regime when temperatures increased by $6{ }^{\circ} \mathrm{C}$ at all sites (except Komatipoort, $+0.5 \%$ ), and further declined very rapidly as temperature increased to $+9{ }^{\circ} \mathrm{C}$. SDM changes at the $+9{ }^{\circ} \mathrm{C}$ regime ranged from $-17.5 \%$ at Ayr to $-10.6 \%$ at Ligne Paradis (Table 5). The highest $\mathrm{RUE}_{\mathrm{A}}$ values were achieved at $+3{ }^{\circ} \mathrm{C}$ for all sites except for Ligne Paradis, where the baseline regime had the highest average $\mathrm{RUE}_{\mathrm{A}}$ value.

Evapotranspiration (ET) increased sharply $\left(34.1 \%\right.$ on average at $\left.+9{ }^{\circ} \mathrm{C}\right)$ with increasing temperature at all irrigated sites, causing increased irrigation demand (38\% at Chiredzi to $62 \%$ at Ligne Paradis for the $+9{ }^{\circ} \mathrm{C}$ ) at all sites (Table 5). This is caused primarily by very large increases in atmospheric evaporative demand as temperature increased (18-48\% increases at $+9^{\circ} \mathrm{C}$ ). Small increases in FiPAR at some sites (e.g. Ligne Paradis) and temperature regimes $\left(+3{ }^{\circ} \mathrm{C}\right)$, caused by accelerated canopy development, also contributed.

Increasing [CO2] reduced ET at all irrigated sites, with decreases ranging from $-4.4 \%$ at Ligne Paradis to $-12.9 \%$ at Ayr for the $750 \mathrm{ppm}$ [CO2] regime. This caused a decrease in irrigation demand for all sites, ranging from $-4.7 \%$ for Chiredzi to $-12.9 \%$ for Ayr (Table 5). $\mathrm{RUE}_{\mathrm{A}}$ showed no response to [CO2], as expected. TE $\mathrm{A}_{\mathrm{A}}$ was higher at cooler climates, 
declined with increasing temperature, and increased with increasing [CO2] (Table 5). $\mathrm{TE}_{\mathrm{A}}$ increases varied from $1.4 \%$ per 100 ppm change in [CO2] for Ligne Paradis, to $4.4 \%$ per 100 ppm for Ayr. These are much lower than the value of $8 \%$ per 100 ppm used as model parameter by Webster et al. (2009).

$\mathrm{RUE}_{\mathrm{A}}$ values ranged from 1.11 to $1.25 \mathrm{~g} / \mathrm{MJ}$ (Table 5), which fall within the observed range reported by Singels et al. (2005a), and agree with values of 1.15 and $1.24 \mathrm{~g} / \mathrm{MJ}$ reported by Anderson et al. (2014), but are lower than values of around $1.45 \mathrm{~g} / \mathrm{MJ}$ reported by Robertson et al. (1996).

Results for rainfed sites are given in Table 6. Average SDM increased with increasing relative rainfall for both sites with a bigger response simulated for La Mercy than for Piracicaba (13.9 vs $6.9 \%$ at the $+25 \%$ regime). Similarly, SDM decreased with decreasing rainfall, with La Mercy showing a bigger decrease than Piracicaba. This was brought about by improved crop water status (as reflected by $S W S I_{P T}$ ) with increasing rainfall. RUE $_{\mathrm{A}}$ and $\mathrm{TE}_{\mathrm{A}}$ values also increased with increasing rainfall as a consequence of improved water status (Table 6).

The highest average SDM for both sites was achieved at the $+3{ }^{\circ} \mathrm{C}$ temperature regime. SDM declined rapidly with further temperature increases. SDM changes for La Mercy were larger than those for Piracicaba, because the crop water status was less favourable and also changed more drastically with temperature changes. The highest $\mathrm{RUE}_{\mathrm{A}}$ values were achieved at the $+3{ }^{\circ} \mathrm{C}$ regime for Piracicaba, and for the baseline regime for La Mercy. $\mathrm{TE}_{\mathrm{A}}$ declined with increasing temperature at both sites, as can be expected (Table 6). 
Table 5. Irrigated sites sensitivity analysis values for fractional interception of photosynthetically active radiation (FiPAR), cumulative seasonal irrigation requirement

(IRR), cumulative seasonal evapotranspiration (ET), stalk dry mass at harvest (SDM), apparent crop radiation use efficiency $\left(R U E_{A}\right)$, and apparent crop transpiration efficiency $\left(T E_{A}\right)$; simulations were conducted with the V4.5_C2.2 model.

\begin{tabular}{|c|c|c|c|c|c|c|c|}
\hline Site & Treatment & FiPAR & $\begin{array}{c}\text { IRR } \\
(\mathbf{m m})\end{array}$ & $\begin{array}{c}\text { ET } \\
(\mathbf{m m})\end{array}$ & $\begin{array}{l}\text { SDM } \\
\text { (t/ha) }\end{array}$ & $\begin{array}{l}\mathbf{R U E}_{\mathbf{A}} \\
(\mathrm{g} / \mathbf{M J})\end{array}$ & $\begin{array}{c}\mathrm{TE}_{\mathrm{A}} \\
(\mathrm{g} / \mathrm{kg})\end{array}$ \\
\hline \multirow[t]{9}{*}{ Ayr, Australia } & Baseline & 0.84 & 1003 & 1422 & 47.3 & 1.18 & 5.79 \\
\hline & Temp. $-3^{\circ} \mathrm{C}$ & 0.80 & 906 & 1320 & 43.2 & 1.15 & 6.15 \\
\hline & Temp. $+3{ }^{\circ} \mathrm{C}$ & 0.85 & 1113 & 1537 & 47.8 & 1.16 & 5.27 \\
\hline & Temp. $+6^{\circ} \mathrm{C}$ & 0.83 & 1271 & 1707 & 44.7 & 1.13 & 4.74 \\
\hline & Temp. $+9{ }^{\circ} \mathrm{C}$ & 0.76 & 1453 & 1926 & 39.0 & 1.14 & 4.36 \\
\hline & $\mathrm{CO}_{2} 450 \mathrm{ppm}$ & 0.84 & 962 & 1383 & 47.3 & 1.18 & 5.98 \\
\hline & $\mathrm{CO}_{2} 550 \mathrm{ppm}$ & 0.84 & 918 & 1335 & 47.3 & 1.18 & 6.23 \\
\hline & $\mathrm{CO}_{2} 650 \mathrm{ppm}$ & 0.84 & 879 & 1284 & 47.3 & 1.18 & 6.51 \\
\hline & $\mathrm{CO}_{2} 750 \mathrm{ppm}$ & 0.84 & 838 & 1239 & 47.3 & 1.18 & 6.78 \\
\hline \multirow{9}{*}{$\begin{array}{l}\text { Ligne Paradis, } \\
\text { Reunion } \\
\text { Island }\end{array}$} & Baseline & 0.79 & 824 & 1259 & 45.4 & 1.25 & 6.63 \\
\hline & Temp. $-3^{\circ} \mathrm{C}$ & 0.73 & 757 & 1171 & 39.1 & 1.22 & 7.02 \\
\hline & Temp. $+3{ }^{\circ} \mathrm{C}$ & 0.83 & 915 & 1341 & 45.7 & 1.17 & 5.85 \\
\hline & Temp. $+6{ }^{\circ} \mathrm{C}$ & 0.85 & 1067 & 1464 & 44.4 & 1.11 & 5.13 \\
\hline & Temp. $+9{ }^{\circ} \mathrm{C}$ & 0.81 & 1338 & 1638 & 40.6 & 1.09 & 4.58 \\
\hline & $\mathrm{CO}_{2} 450 \mathrm{ppm}$ & 0.79 & 804 & 1248 & 45.4 & 1.25 & 6.70 \\
\hline & $\mathrm{CO}_{2} 550 \mathrm{ppm}$ & 0.79 & 804 & 1234 & 45.4 & 1.25 & 6.79 \\
\hline & $\mathrm{CO}_{2} 650 \mathrm{ppm}$ & 0.79 & 776 & 1219 & 45.4 & 1.25 & 6.90 \\
\hline & $\mathrm{CO}_{2} 750 \mathrm{ppm}$ & 0.79 & 768 & 1204 & 45.4 & 1.25 & 7.00 \\
\hline \multirow{9}{*}{$\begin{array}{l}\text { Komatipoort, } \\
\text { South Africa }\end{array}$} & Baseline & 0.80 & 700 & 1146 & 43.1 & 1.23 & 6.40 \\
\hline & Temp. $-3{ }^{\circ} \mathrm{C}$ & 0.75 & 534 & 959 & 35.3 & 1.15 & 6.54 \\
\hline & Temp. $+3{ }^{\circ} \mathrm{C}$ & 0.82 & 871 & 1330 & 45.1 & 1.23 & 5.86 \\
\hline & Temp. $+6{ }^{\circ} \mathrm{C}$ & 0.82 & 998 & 1477 & 43.3 & 1.20 & 5.22 \\
\hline & Temp. $+9{ }^{\circ} \mathrm{C}$ & 0.78 & 1071 & 1564 & 38.1 & 1.19 & 4.65 \\
\hline & $\mathrm{CO}_{2} 450 \mathrm{ppm}$ & 0.80 & 690 & 1133 & 43.1 & 1.23 & 6.47 \\
\hline & $\mathrm{CO}_{2} 550 \mathrm{ppm}$ & 0.80 & 678 & 1117 & 43.1 & 1.23 & 6.56 \\
\hline & $\mathrm{CO}_{2} 650 \mathrm{ppm}$ & 0.80 & 653 & 1100 & 43.1 & 1.23 & 6.67 \\
\hline & $\mathrm{CO}_{2} 750 \mathrm{ppm}$ & 0.80 & 641 & 1083 & 43.2 & 1.23 & 6.76 \\
\hline \multirow{9}{*}{$\begin{array}{l}\text { Chiredzi, } \\
\text { Zimbabwe }\end{array}$} & Baseline & 0.83 & 1117 & 1280 & 47.1 & 1.23 & 6.82 \\
\hline & Temp. $-3{ }^{\circ} \mathrm{C}$ & 0.79 & 1014 & 1176 & 40.3 & 1.13 & 7.61 \\
\hline & Temp. $+3{ }^{\circ} \mathrm{C}$ & 0.83 & 1229 & 1394 & 48.2 & 1.23 & 5.80 \\
\hline & Temp. $+6{ }^{\circ} \mathrm{C}$ & 0.81 & 1376 & 1548 & 45.5 & 1.19 & 5.04 \\
\hline & Temp. $+9{ }^{\circ} \mathrm{C}$ & 0.76 & 1537 & 1719 & 39.8 & 1.16 & 4.55 \\
\hline & $\mathrm{CO}_{2} 450 \mathrm{ppm}$ & 0.83 & 1108 & 1268 & 47.1 & 1.23 & 6.92 \\
\hline & $\mathrm{CO}_{2} 550 \mathrm{ppm}$ & 0.83 & 1093 & 1253 & 47.1 & 1.23 & 7.04 \\
\hline & $\mathrm{CO}_{2} 650 \mathrm{ppm}$ & 0.83 & 1075 & 1237 & 47.1 & 1.23 & 7.18 \\
\hline & $\mathrm{CO}_{2} 750 \mathrm{ppm}$ & 0.83 & 1065 & 1221 & 47.1 & 1.23 & 7.32 \\
\hline
\end{tabular}


Increased [CO2] caused a small increase in SDM for the two rainfed sites $(+7.4 \%$ and $+5.6 \%$ at $750 \mathrm{ppm}$ respectively for La Mercy and Piracicaba). Although ET declined a little with increasing [CO2], it was not enough to improve significantly the water status of crops. Interestingly, $\mathrm{RUE}_{\mathrm{A}}$ values increased slightly with increasing [CO2] for both sites $(\sim 1 \%$ per $100 \mathrm{ppm}$ ), despite the zero $\mathrm{CO}_{2}$ fertilizer response assumed in simulations. The magnitude of the $\mathrm{RUE}_{\mathrm{A}}$ change corresponds well with the $1.43 \%$ change in maximum RUE per $100 \mathrm{ppm}$ assumed by Webster et al., (2009). $\mathrm{TE}_{\mathrm{A}}$ increased with increasing [CO2] for both sites, but at a lower rate than that for irrigated sites, as can be expected.

\subsubsection{In-depth analysis of results for South African sites}

At Komatipoort, results for the V4.5_C2.2 model showed that average FiPAR increased with increasing temperature, peaking at the $+6{ }^{\circ} \mathrm{C}$ regime, and declining somewhat with a further $3{ }^{\circ} \mathrm{C}$ increase $\left(+9^{\circ} \mathrm{C}\right.$ ) (Figure 2). These responses are more pronounced than the data presented in Table 5 because the April (autumn) cycle crops included in the simulations used for these in-depth analyses are more responsive to temperature changes, due to lower baseline temperatures during the first few months of crop growth, compared with October starts. The V4.5_C1.1 version showed a similar response in FiPAR except for the $+9{ }^{\circ} \mathrm{C}$ regime where FiPAR did not decline compared with the $+6{ }^{\circ} \mathrm{C}$ regime. This difference in model behaviour is the result of the different calculations of effective temperature, with version V4.5_C2.2 taking into account an upper limit (Equations (1) to (3)). ET increased dramatically with increasing temperature, due to the marked increase in evaporative demand, and also because of the increased rate of canopy development as represented by FiPAR. 
Table 6. Rainfed sites sensitivity analysis values for soil water satisfaction index ( $\left.S W S I_{P T}\right)$, fractional interception of photosynthetically-active radiation (FiPAR), cumulative seasonal evapotranspiration (ET), stalk dry mass at harvest (SDM), apparent crop radiation use efficiency $\left(R U E_{A}\right)$, and apparent crop transpiration efficiency $\left(T E_{A}\right)$; simulations were conducted with the V4.5_C2.2 model.

\begin{tabular}{|c|c|c|c|c|c|c|c|}
\hline Site & Treatment & SWSI $_{P T}$ & FiPAR & $\begin{array}{c}\mathbf{E T} \\
(\mathbf{m m})\end{array}$ & $\begin{array}{l}\text { SDM } \\
\text { (t/ha) }\end{array}$ & $\begin{array}{l}\mathbf{R U E}_{\mathbf{A}} \\
(\mathrm{g} / \mathbf{M J})\end{array}$ & $\begin{array}{c}\mathbf{T E}_{\mathbf{A}} \\
(\mathbf{g} / \mathbf{k g})\end{array}$ \\
\hline \multirow{13}{*}{$\begin{array}{l}\text { Piracicaba, } \\
\text { Brazil }\end{array}$} & Baseline & 0.84 & 0.78 & 1015 & 30.5 & 1.04 & 6.67 \\
\hline & Temp. $-3{ }^{\circ} \mathrm{C}$ & 0.85 & 0.73 & 995 & 23.6 & 0.92 & 6.46 \\
\hline & Temp. $+3{ }^{\circ} \mathrm{C}$ & 0.82 & 0.80 & 1055 & 32.6 & 1.05 & 6.20 \\
\hline & Temp. $+6{ }^{\circ} \mathrm{C}$ & 0.79 & 0.77 & 1128 & 30.1 & 1.00 & 5.41 \\
\hline & Temp. $+9{ }^{\circ} \mathrm{C}$ & 0.74 & 0.69 & 1216 & 22.9 & 0.89 & 4.51 \\
\hline & Rainfall $-25 \%$ & 0.77 & 0.75 & 937 & 26.8 & 0.97 & 6.61 \\
\hline & Rainfall $-10 \%$ & 0.82 & 0.77 & 990 & 29.3 & 1.02 & 6.64 \\
\hline & Rainfall $+10 \%$ & 0.85 & 0.79 & 1036 & 31.6 & 1.06 & 6.70 \\
\hline & Rainfall $+25 \%$ & 0.87 & 0.79 & 1062 & 32.6 & 1.09 & 6.71 \\
\hline & $\mathrm{CO}_{2} 450 \mathrm{ppm}$ & 0.84 & 0.78 & 1008 & 30.9 & 1.05 & 6.81 \\
\hline & $\mathrm{CO}_{2} 550 \mathrm{ppm}$ & 0.85 & 0.78 & 997 & 31.3 & 1.06 & 6.99 \\
\hline & $\mathrm{CO}_{2} 650 \mathrm{ppm}$ & 0.86 & 0.79 & 986 & 31.8 & 1.07 & 7.19 \\
\hline & $\mathrm{CO}_{2} 750 \mathrm{ppm}$ & 0.86 & 0.79 & 975 & 32.2 & 1.08 & 7.38 \\
\hline \multirow{13}{*}{$\begin{array}{l}\text { La Mercy, } \\
\text { South } \\
\text { Africa }\end{array}$} & Baseline & 0.75 & 0.72 & 722 & 21.6 & 0.87 & 7.65 \\
\hline & Temp. $-3{ }^{\circ} \mathrm{C}$ & 0.81 & 0.66 & 650 & 13.7 & 0.73 & 7.29 \\
\hline & Temp. $+3{ }^{\circ} \mathrm{C}$ & 0.67 & 0.73 & 788 & 22.3 & 0.83 & 6.46 \\
\hline & Temp. $+6{ }^{\circ} \mathrm{C}$ & 0.60 & 0.71 & 828 & 19.6 & 0.73 & 5.26 \\
\hline & Temp. $+9{ }^{\circ} \mathrm{C}$ & 0.56 & 0.64 & 852 & 14.8 & 0.64 & 4.31 \\
\hline & Rainfall $-25 \%$ & 0.66 & 0.67 & 640 & 16.7 & 0.75 & 7.45 \\
\hline & Rainfall $-10 \%$ & 0.72 & 0.70 & 694 & 19.9 & 0.83 & 7.59 \\
\hline & Rainfall $+10 \%$ & 0.77 & 0.73 & 746 & 22.9 & 0.90 & 7.69 \\
\hline & Rainfall $+25 \%$ & 0.80 & 0.74 & 777 & 24.6 & 0.94 & 7.75 \\
\hline & $\mathrm{CO}_{2} 450 \mathrm{ppm}$ & 0.75 & 0.72 & 719 & 21.9 & 0.88 & 7.79 \\
\hline & $\mathrm{CO}_{2} 550 \mathrm{ppm}$ & 0.76 & 0.72 & 713 & 22.3 & 0.89 & 7.97 \\
\hline & $\mathrm{CO}_{2} 650 \mathrm{ppm}$ & 0.76 & 0.73 & 708 & 22.8 & 0.90 & 8.18 \\
\hline & $\mathrm{CO}_{2} 750 \mathrm{ppm}$ & 0.77 & 0.73 & 703 & 23.2 & 0.91 & 8.37 \\
\hline
\end{tabular}


The highest average SDM for Komatipoort, using the V4.5_C2.2 model, was produced for the $+3{ }^{\circ} \mathrm{C}$ regime. SDM decreased sharply at the $-3{ }^{\circ} \mathrm{C}$ regime, and also decreased somewhat at $+6{ }^{\circ} \mathrm{C}$, and substantially at the $+9{ }^{\circ} \mathrm{C}$ regime. However, the decreased SDM at $+9{ }^{\circ} \mathrm{C}$ is largely due to increased frequency of temperatures exceeding the optimal range for net photosynthesis. The number of days on which mean daily air temperature exceeded $30{ }^{\circ} \mathrm{C}$ was 230 for the $+9{ }^{\circ} \mathrm{C}$ regime, compared to 147,52 and 5 for $+6{ }^{\circ} \mathrm{C},+3{ }^{\circ} \mathrm{C}$ and the baseline regimes respectively. Although the V4.5_C1.1 version showed a similar SDM trend, the reductions at the high temperature regimes were less pronounced.

ET at Komatipoort (V4.5_C2.2) was reduced with increasing [CO2], reaching about $-5.5 \%$ at 750 ppm. Average SDM at elevated [CO2] was slightly higher than that of the baseline. This is ascribed to the alleviation of short periods of mild water stress when simulated irrigation could not keep up with crop demand.

At La Mercy, for V4.5_C2.2, average FiPAR increased with increasing temperature up to $+6{ }^{\circ} \mathrm{C}$, driven mainly by accelerated thermal time accumulation. FiPAR declined slightly for the $+9{ }^{\circ} \mathrm{C}$ regime, compared to that of the $+6{ }^{\circ} \mathrm{C}$ regime (Figure 3 ), due to a combination of (1) elevated water stress and (2) little added advantage of higher temperatures, as these more frequently exceeded $T_{U}$ and $T_{O}$ (Equation (3)) for the relevant processes. ET also increased with increasing temperature, due to a marked increase in evaporative demand, as well as in FiPAR. Average crop water status deteriorated markedly with increasing temperature (SWSI in Figure 3), which caused a decline in SDM for high temperature regimes. The highest average SDM was simulated for the baseline regime. Low FiPAR for $-3{ }^{\circ} \mathrm{C}$ contributed to the reduced SDM for this regime. Temperature-induced changes in FiPAR and SDM, simulated by the V4.5_C1.1 version, were less pronounced than those simulated by the V4.5_C2.2 version. 
Increasing [CO2] decreased ET at La Mercy (by about 3\% at $750 \mathrm{ppm}$ compared to the baseline) with V4.5_C2.2, which led to small improvements in crop water status (SWSI $I_{P T}$ increased by about $4 \%$ at $750 \mathrm{ppm}$ compared to the baseline) (Figure 2). Small increases in average FiPAR, in response to increased [CO2], were simulated as a consequence of the improved water status. The combination of these responses resulted in SDM increases at elevated [CO2] (about 7\% at $750 \mathrm{ppm})$.

The V4.5_C1.1 version simulated larger increases in SDM at La Mercy and Komati in response to increased [CO2], due to the simulated fertilisation effect, which was removed in V4.5_C2.2. In general, the simulated crop response to elevated atmospheric $\mathrm{CO}_{2}$ concentration is regarded as realistic and reflecting the latest thinking and knowledge.

The average progression of FiPAR, simulated by the V4.5_C1.1 and V4.5_C2.2 model versions, for the different crop cycles grown at Komatipoort, is shown in Figure 2. For the V4.5_C2.2 model, for the April crop, relatively large responses were simulated for the $+3{ }^{\circ} \mathrm{C}$ regime. For temperature increases of more than $3{ }^{\circ} \mathrm{C}$, the responses were very small. In the October crop responses were much less pronounced because of the warmer start to the season, compared to the April start. A comparison of the simulated responses between the two models (Figure 2) shows that the unrealistic simulation of continued acceleration of canopy development with increasing temperature by V4.5_C1.1 was corrected in V4.5_C2.2, through a revised calculation of thermal time.

These results confirm the importance of simulating and evaluating crop process responses to climate change in different crop cycles to gain a good understanding of climate change impacts on sugarcane development and growth. 
Komatipoort, April, V4.5_C2.2

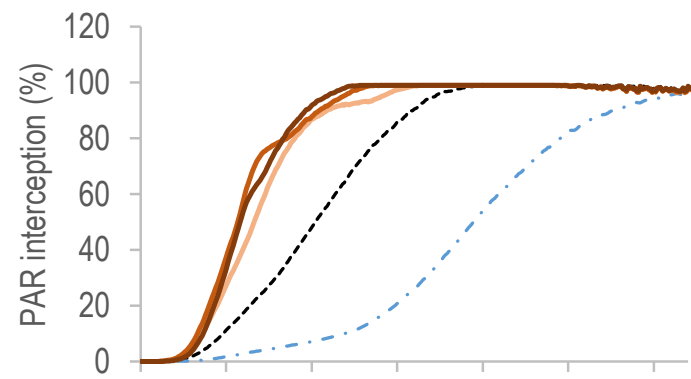

Komatipoort, October, V4.5_C2.2

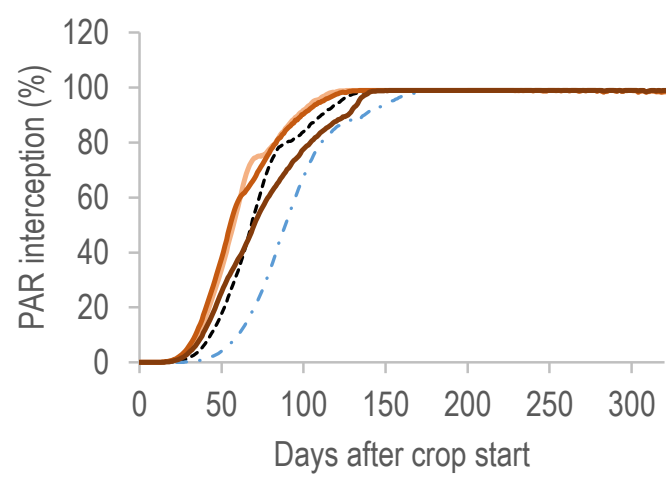

------- Baseline - - - - $-3{ }^{\circ} \mathrm{C}$ $+6{ }^{\circ} \mathrm{C}$
Komatipoort, April, V4.5_C1.1

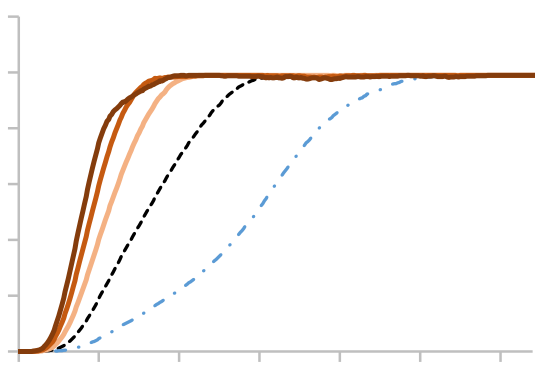

Komatipoort, October, V4.5_C1.1

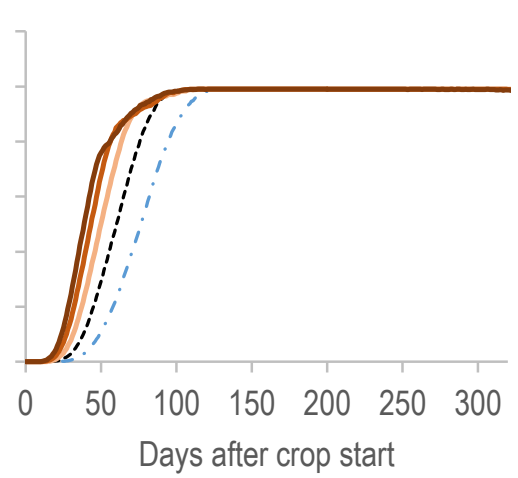

Figure 2. Long-term average fractional interception of PAR over the growing season for the different temperature regimes for crops started in April and October at Komatipoort, as simulated by V4.5_C2.2 (left) and V4.5_C1.1 (right) models. 

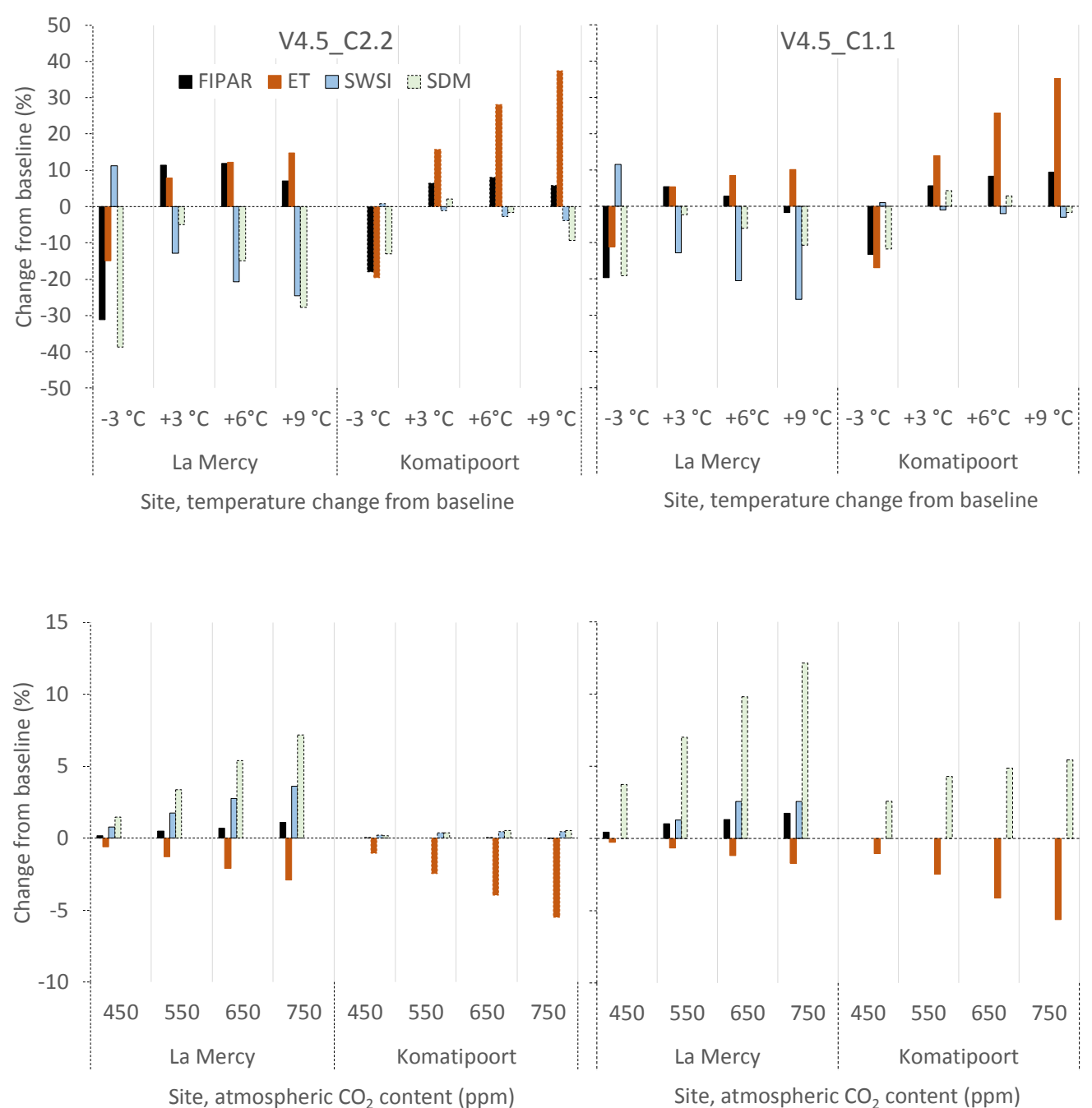

Figure 3. Change in long term mean (average for crops starting in April and October) seasonal interception of radiation (FiPAR), evapotranspiration (ET),

photosynthesis/transpiration soil water satisfaction index (SWSI) and stalk dry mass at harvest (SDM) for different temperature regimes $\left(-3,+3,+6\right.$, and $+9{ }^{\circ} \mathrm{C}$ change from the baseline) and different atmospheric $\mathrm{CO}_{2}$ levels (450, 550, 650 and 750 ppm) at La Mercy and Komatipoort, expressed as a percentage of that of the baseline regime, as simulated by the V4.5_C2.2 (left) and V4.5_C1.1 (right) models. 
Results from the sensitivity analysis confirm that the changes introduced in the V4.5_C2.2 model enabled more realistic simulation of sugarcane responses to changes in rainfall, temperature and [CO2]. In particular, the responses to elevated temperatures are more realistic. Crop development and growth are now negatively affected by very high temperatures in the absence of water stress. The V4.5_C1.1 model was lacking in this regard.

\section{DISCUSSION}

Model validation results indicate that the accuracy of the refined V4.5_C2.2 model is similar to V4.5_C1.1, and compares favourably with previous SDM validations by O’Leary (2000) Singels \& Bezuidenhout (2002), Singels et al. (2010), Marin et al. (2011), Jones (2013), Marin et al. (2015), and Jones et al. (2014) (RMSE of 5.2 compared with 11.1, 5.5, 13-33, 9.7, 6.6, 9.0 and 18.3 t/ha respectively). V4.5_C2.2 performance also compares reasonably favourable with that reported for other models. O’Leary (2000), Thorburn et al. (2011), Thorburn et al. (2014), Marin et al. (2015), Meier and Thorburn (2016) and Inman-Bamber et al. (2016) reported SDM RMSEs for the APSIM-Sugar model of 6.0, 4.7, 18.9, 20.1, 13-16 and $7.9 \mathrm{t} /$ ha respectively. O'Leary (2000) indicated an SDM RMSE of $6.11 \mathrm{t} /$ ha for the QCANE (Liu and Bull, 2001) model, while a new process-based model (Marin and Jones, 2014) achieved an SDM RMSE of $5.38 \mathrm{t} / \mathrm{ha}$ for validation sites in Brazil. While it is difficult to make a clear comparison of performance between different model families, given differences in validation datasets and calibration philosophies, it appears that the DSSATCanegro V45_C2.2 model developed in this study provides satisfactory performance. It should be noted, however, that the refined canopy development and water uptake simulations 
have not been validated against observed data of canopy cover and soil water content. A focused evaluation with appropriate experimental data is recommended.

The intention of the sensitivity analysis was to explore, understand and explain the refined model's responses to key climate change drivers, in order to assess the model's suitability for use in climate change impact studies. Results from the refined model are more realistic (as demonstrated in response patterns of key crop parameters) - particularly under high temperature regimes - than the current model. The refinements to the simulation of crop water relations and temperature control of canopy development, as well as the assumed zero $\mathrm{CO}_{2}$ fertilisation effect, had a marked effect on the simulated response of SDM to temperature regime changes for diverse climates. In general, the refined model (V4.5_C2.2) simulated less favourable SDM responses to temperature changes than the current model (V4.5_C1.1), with decreases from the baseline for the $-3{ }^{\circ} \mathrm{C},+6{ }^{\circ} \mathrm{C}$ and $+9{ }^{\circ} \mathrm{C}$ temperature regimes at almost all sites and crop cycles. The V4.5_C1.1 model seems to simulate a more favourable impact of temperature regime change, with SDM increases up to $+6^{\circ} \mathrm{C}$ for sites in Brazil (Marin et al., 2014), and Komatipoort (Figure 3 this study). It is recommended that past climate change impact and adaptation studies utilising the Canegro model be revisited.

The study highlighted a few areas for model improvement and further research. Firstly, some uncertainty remains regarding the direct effect of elevated [CO2] on photosynthesis. For example, the APSIM-sugar model assumes a linear increase in maximum radiation use efficiency (photosynthetic capacity) of $1.43 \%$ per 100 ppm increase in [CO2] (Webster et al., 2009). We based our zero-fertilisation effect in the absence of water stress on recent findings by Stokes et al. (2016) and van Heerden et al. (2016). We acknowledge, nevertheless, that this could be an oversimplification. For example, calculating water stress on a daily (rather than hourly) time step might result in underestimations of transient midday water stress (see Inman-Bamber et al., 2016), thus underestimating the indirect effect of [CO2] on biomass 
accumulation via transpiration efficiency. Provision has been made in the DSSAT-Canegro model for accommodating a flexible direct [CO2] effect on gross photosynthesis via species parameters (Table A2 in Appendix A), should compelling new evidence - results of a free air carbon enrichment (FACE) experiment, for example - come to light.

Secondly, the calculation of the elevated [CO2] effect on transpiration may be improved by adopting the Penman-Monteith approach that makes use of variable, rather than reference, values for crop height and leaf area index to derive boundary layer resistance $(R A)$, following Stokes et al. (2016) and Everingham et al. (2015). Stokes et al. (2016) demonstrated that when LAI is small and crop height is low, $R A$ is relatively small and the effect of increasing [CO2] from 375 to $720 \mathrm{ppm}$ on $R S$ and transpiration is relatively large (up to $30 \%$ reduction in transpiration), compared to a more mature crop (5-20\% reduction in transpiration). This dynamic cannot be simulated in the DSSAT algorithm because it uses a reference crop height and LAI for calculating transpiration.

Thirdly, $\mathrm{RUE}_{\mathrm{A}}$ in sugarcane has been observed to decrease as the crop ages, particularly in high growth potential environments (see review by van Heerden et al., 2010). This has been termed the 'reduced growth phenomenon' (RGP) by Park et al. (2005). The four main reasons for RGP postulated by van Heerden et al. (2010) are lodging with or without stalk death, declining specific leaf nitrogen, feedback inhibition of photosynthesis by high sugar content in mature cane, and high respiratory demand in large crops. The DSSAT-Canegro V4.5_C2.2 model accounts partially for this phenomenon via the simulation of maintenance respiration and lodging. APSIM-Sugar (Keating et al., 1999) has the ability to simulate the crop response to user specified lodging events. Other RGP mechanisms are not included. As far as we could ascertain, the Mosicas sugarcane model (Martine \& Todoroff, 2004) does not simulate RGP processes. It is clear that additional work is necessary to understand and then simulate the processes that may cause RGP. Addressing this knowledge gap is particularly 
important in the context of climate change impact studies, as there is a risk that climate change may exacerbate this phenomenon.

The model shortcomings addressed in this study prepare DSSAT-Canegro for more robust application in climate change studies, and it is intended that these changes will be implemented in a future release of DSSAT v4.6 or v4.7. The inclusion of this refined DSSAT-Canegro model into sugarcane climate change studies may lead to more accurate and relevant research outcomes, including evaluation of climate change impacts and exploration of climate change adaptation strategies, as well as future model improvements.

\section{CONCLUSIONS}

The Canegro model was refined to improve its capabilities for simulating climate change impacts on crop growth and development, in particular the response to changes in temperature and $[\mathrm{CO} 2]$. The refined model demonstrated acceptable simulation accuracy (RMSE for ADM, SDM and SUCM prediction of $8.4,5.2$ and $3.3 \mathrm{t} /$ ha respectively). Its performance was similar to that of the old Canegro model, and compared well with that of other established sugarcane models. Model evaluation also revealed that disabling the simulation of maintenance respiration as a function of temperature and live biomass did not improve simulation accuracy.

An analysis of the sensitivity of simulated canopy formation, crop water use, crop water status and stalk dry mass to changes in rainfall, temperature and [CO2] suggests that predictions by the refined model of climate factor impacts are more realistic and plausible than that of the old model. Highest average simulated stalk mass for all scenarios was achieved at a temperature regime that was $3{ }^{\circ} \mathrm{C}$ warmer than current climate, with yield increases ranging from $0.7 \%$ (irrigated Ligne Paradis, Reunion Island) to $7 \%$ (rainfed 
Piracicaba, Brazil). Elevated [CO2] increased yields for rainfed production (7\% for La Mercy, South Africa, and $6 \%$ for Piracicaba, at $750 \mathrm{ppm}$ [CO2]) through reduced transpiration and improved crop water status.

The study highlighted areas that require further attention. The new canopy development and water uptake algorithms require a thorough evaluation against observed data. The capability of sugarcane models for simulating reduced growth of older crops, and [CO2] effects on transpiration, needs to be improved. The reliability of climate change impact predictions will also improve when the uncertainty regarding the $\mathrm{CO}_{2}$ fertilization effect is resolved and appropriately simulated in sugarcane models. This study has delivered an improved Canegro model that contains more realistic representations of plant processes and their interaction with climatic drivers, and is capable of predicting crop growth, water use and yields for a wide range of climates with reasonable accuracy. It is recommended that the model be incorporated into the latest DSSAT package.

\section{ACKNOWLEDGEMENTS}

The provision of weather data and soil information for the sensitivity analysis by Peter Thorburn of CSIRO, Simbarashe Chinorumba of ZSAES, Fabio Marin of USP, and JeanFrancois Martine of CIRAD, is gratefully acknowledged.

The authors extend heartfelt thanks to Geoff Inman-Bamber for his guidance and support over an extended time, and to Natalie Hoffman and Sanele Khambule at SASRI for their assistance. 
The authors are also grateful to the AgMIP leadership team, and in particular Peter Thorburn and Alex Ruane (NASA GISS), for developing the AgMIP protocols and for their support in facilitating the implementation of these protocols.

Support and funding from the S.A. sugar industry through SASRI for this work are gratefully acknowledged.

\section{REFERENCES}

Allen, R.G., Pereira, L.S., Raes, D. and Smith, M. 1998. Crop evapotranspiration: guidelines for computing crop water requirements. In: FAO Irrigation and Drainage Paper 56. Food and Agriculture Organisation of the United Nations, Rome, Italy.

Allen, L. H. Jr., Vu, J. C. V., Anderson, J. C. and Ray, J. D. 2011. Impact of elevated carbon dioxide and temperature on growth and sugar yield of the $\mathrm{C} 4$ sugarcane. Current Topics in Plant Biology 11: 171-178.

Allen, L.H., Jones, P. and Jones, J.W. 1985. Rising atmospheric $\mathrm{CO}_{2}$ and evapotranspiration. In: Proceedings of the National Conference on Advances in Evapotranspiration held in Chicago, Illinois from 16-17 December 1985. ASAE publication, St Joseph, Michigan, pp. $13-27$.

Amthor, J.S. 2000. The McCree-Penning De Vries-Thornley paradigms: 30 years later. Annals of Botany 86: 1-20.

Anderson, R.G., Tirado-Corbalá, R., Wang, D. and Ayars, J.E. 2014. Long-rotation sugarcane in Hawaii sustains high carbon accumulation and radiation use efficiency in 2nd year of growth. Agriculture, Ecosystems and Environment 199: 216-224. 
Bieleski, R.L. 1958. The physiology of sugarcane. II. The respiration of harvested sugarcane. Aust. J. Biol. Sci. 11: 315-328.

Biggs, J.S., Thorburn, P.J., Crimp, S., Masters, B., Attard, S.J., 2013. Interactions between climate change and sugarcane management systems for improving water quality leaving farms in the Mackay Whitsunday region. Aust. Agric. Ecosyst. Environ. 180, 79-89.

Bonnet, G., Hewitt, M.L. and Glassop, D. 2006. Effect of high temperature on the growth and composition of sugarcane internodes. Aust. J Agric. Res. 57:1087-1095.

Boote, K.J., Allen, L.H. Jr., Prasad, P.V.V. and Jones, J.W. 2010. Testing effects of climate change in crop models. In: Hillel, D. and Rosenzweig. C. (eds). Handbook of climate change and agro-ecosystems: Impacts, adaptation, and mitigation., ICP series on climate change impacts, adaptation, and mitigation Vol. 1. Imperial College Press pp. 109-129.

Campbell, J.A., Robertson, M.J. and Grof, C.P.L. 1998. Temperature effects on node appearance in sugarcane. Australian Journal of Plant Physiology 25: 815-818.

Cheeroo-Nayamuth, F.B., Bezuidenhout, C.N., Kiker, G.A. and Nayamuth, A.R.H. 2003. Validation of Canegro-DSSAT V3.5 for contrasting sugarcane varieties in Mauritius. Proceedings of the Annual Congress - South African Sugar Technologists' Association 77:601-604.

De Carvalho, A.L., Menezes, R.S.C., Nobrega, R.S., de Siqueira Pinto, A., Ometto, J.P.H.B., von Randow, C. and Giarolla, A., 2015. Impact of climate changes on potential sugarcane yield in Pernambuco, north-eastern region of Brazil. Renewable Energy 78: 26-34.

De Souza, A.P., Gaspar, M., da Silva, E.A., Ulian, E.C., Waclawovsky, A.J., Nishiyama M.Y.Jr., dos Santos, R.V., Teixeira, M.M., Souza, G.M., Buckeridge, M.S. 2008. Elevated 
$\mathrm{CO} 2$ increases photosynthesis, biomass and productivity, and modifies gene expression in sugarcane. Plant, Cell and Environment 31: 1116-1127.

Doorenbos, J. and Kassam, A.H. 1979. Yield Response to Water. Food and Agriculture Organization of the United Nations, Rome, FAO Irrigation and Drainage Paper 33, p. 193.

Ebrahim, M.K., Vogg, G., Osman, M.N.E.H. and Komor, E. 1998. Photosynthetic performance and adaptation of sugarcane at suboptimal temperatures. J Plant Physiology: 153: 587-592.

Everingham, Y., Inman-Bamber, N.G., Sexton, J. and Stokes, C. 2015. A dual ensemble agroclimate modelling procedure to assess climate change impacts on sugarcane production in Australia. Agricultural Sciences 6: 870-888.

FAO, 2016. FAOSTAT beta. Food and Agriculture Organization of the United Nations. http://fenix.fao.org/faostat/beta/en/\#data/QD.

Gifford, R.M. 2003. Plant respiration in productivity models: conceptualization, representation and issues for global terrestrial carbon-cycle research. Functional Plant Biology 30:171-186.

Inman-Bamber, N.G., 1986. The reaction of sugarcane to water stress, Ph.D. Thesis. University of the Orange Free State, Bloemfontein, South Africa, 141 p.

Inman-Bamber, N.G., Jackson, P.A., Stokes, C.J., Verrall, S., Lakshmanan, P. and Basnayake, J. 2016. Sugarcane for water-limited environments: Enhanced capability of the APSIM sugarcane model for assessing traits for transpiration efficiency and root water supply. Field Crops Research 196:112-123. 
Inman-Bamber, N.G. and Thompson, G.D. 1989. Models of dry matter accumulation by sugarcane. Proc. S. Afr. Sug. Technol. Ass. 63: 212-216.

Inman-Bamber, N.G. 1994. Temperature and seasonal effects on canopy development and light interception of sugarcane. Field Crops Research 36:41-51.

Inman-Bamber, N.G. 1991. A growth model for sugar-cane based on a simple carbon balance and the CERES-Maize water balance. S. Afr. J. Plant Soil 8(2):93-99.

IPCC. 2013. Summary for Policymakers. In: Climate Change 2013: The Physical Science Basis. Contribution of Working Group I to the Fifth Assessment Report of the Intergovernmental Panel on Climate Change [Stocker, T.F., D. Qin, G.-K. Plattner, M. Tignor, S.K. Allen, J. Boschung, A. Nauels, Y. Xia, V. Bex and P.M. Midgley (eds.)]. Cambridge University Press, Cambridge, United Kingdom and New York, NY, USA.

Jones, C.A. and Kiniry, J.R. 1986. CERES-Maize Model: A Simulation Model of Maize Growth and Development. Texas A\&M University Press, p. 194.

Jones, J.W., Hoogenboom, G., Porter, C.H., Boote, K.J., Batchelor, W.D., Hunt, L.A., Wilkens, P.W., Singh, U., Gijsman, A.J. and Ritchie, J.T. 2003. The DSSAT cropping system model. European Journal of Agronomy 18:235-265.

Jones, M.R. 2013. Incorporating the Canegro sugarcane model into the DSSAT v4 Cropping System Model framework. Unpublished M.Sc. thesis, University of KwaZulu-Natal, Pietermaritzburg.

Jones, M.R., Singels, A., and Inman-Bamber, N.G. 2011. Simulating source and sink control of structural growth and development and sucrose accumulation in sugarcane. Proc S Afr Sug Technol Ass 84: $157-163$. 
Jones, M.R., Singels, A., Thorburn, P., Marin, F., Martine, J-F., Chinorumba, S., Viator, R. and Nunez, O. 2014. Evaluation of the DSSAT-Canegro model for simulating climate change impacts at sites in seven countries. Proc. S. Afr. Sug. Technol. Ass. 87: 323-329.

Jones, M.R., Singels, A. and Ruane, A. 2015. Simulated impacts of climate change on water use and yield of irrigated sugarcane in South Africa. Agric. Systems 139: 260-270.

Keating, B.A., Robertson, M.J. and Muchow, R.C. 1999. Modeling sugarcane production systems I. Development and performance of the sugarcane module. Field Crops Research 61: 253-271.

Lingle, S.E. 1999. Sugar metabolism during growth and development in sugarcane Internodes. Crop Science 39: 480-486.

Lingle, S.E. and Smith, R.C. 1991 Sucrose metabolism related to growth and ripening in sugarcane internodes. Crop Science 31: 172-177.

Liu, D.L. and Bull, T.A. 2001. Simulation of biomass and sugar accumulation in sugarcane using a process-based model. Ecological Modeling 144: 181-211.

Liu, D.L., Kingston, G. and Bull, T.A. 1998. A new technique for determining the thermal parameters of phenological development in sugarcane, including suboptimum and supraoptimum temperature regimes. Agricultural and Forest Meteorology 90:119-139.

Marin, F.R., Jones, J.W., Royce, F., Suguitani, C., Donzeli, J.L., Pallone Filho, W.J., Nassif, D.S.P. 2011. Parameterization and evaluation of predictions of DSSAT/CANEGRO for Brazilian sugarcane. Agronomy Journal 103: 304-315. 
Marin, F.R., Jones, J.W., Singels, A., Royce, F., Assad, E.D., Pellegrino, G.Q. \& Justino F. 2013. Climate change impacts on sugarcane attainable yield in Southern Brazil. Climatic Change 117: 227-239.

Marin, F. R.; Jones, J. W. 2014. Process-based simple model for simulating sugarcane growth and production. Scientia Agricola 71:1-16.

Marin, F.R., Ribeiro, R.V., Marchiori, P.E.R. 2014. How can crop modeling and plant physiology help to understand the plant responses to climate change? A case study with sugarcane. Theor. Exp. Plant Physiol. 26:49-63.

Marin, F.R, Thorburn, P.J., Nassif, d.S.P., Costa, L.G., 2015. Sugarcane model intercomparison: Structural differences and uncertainties under current and potential future climates. Environmental Modelling \& Software 72: 372-386

Martiné, J.F. and Todoroff, P. 2004. Le modèle de croissance MOSICAS et sa plateforme de simulation simulex: état des lieux et perspectives. Revue agricole et sucrière de l'île Maurice, 80, 133-147 (in French)

Meier E.A. and Thorburn P.J. 2016. Long term sugarcane residue retention offers limited potential to reduce nitrogen fertilizer rates in the Australia Wet tropical environments. Frontiers in Plant Science 7:1017. doi: 10.3389/fpls.2016.01017

O'Leary, G. J. 2000. A review of three sugarcane simulation models with respect to their prediction of sucrose yield. Field Crops Research 68:97-111.

Park, S.E., Robertson, M. and Inman-Bamber, N.G. 2005. Decline in the growth of a sugarcane crop with age under high input conditions. Field Crops Research, 92: 305-320. 
Pinto, H., Sharwood, R. E., Tissue, D. T. and Ghannoum, O. 2014. Photosynthesis of C3, C3-C4, and $\mathrm{C} 4$ grasses at glacial $\mathrm{CO}_{2}$. Journal of Experimental Botany 65: 3669-3681

Raes, D., Steduto, P., Hsiao, T.C. and Fereres, E. 2009. AquaCrop - the FAO crop model to simulate yield response to water: II. Main algorithms and software description. Agronomy Journal 101: 438-447.

Rands, R.D. and Dopp, E. 1938. Pythium root rot of sugar cane US Dept Agric Tech Bull 666: 95 .

Robertson, M.J., Muchow, R.C. and Wood A.W. 1996. Growth of sugarcane under high input conditions in tropical Australia. I. Radiation use, biomass accumulation and partitioning. Field Crops Research 48: 11-25

Robertson, M.H., Bonnet, G.D., Hughes, R.M., Muchow, R.C. and Campbell, J.A. 1998. Temperature and leaf area expansion in sugarcane: integration of controlled environment field and model studies. Aust. J. Plant Physiol. 25: 819-828.

Rosenzweig, C., Jones, J.W., Hatfield, J.L., Ruane, A.C., Boote, K.J., Thorburn, P.J., Antle, J., Nelson, G., Porter, C.H., Janssen, S., Asseng, S., Winter, J.M., and Greeley, A.P. 2013. The Agricultural Model Intercomparison and Improvement Project (AgMIP): protocols and pilot studies. Agricultural and Forest Meteorology 170: 166-182.

Rostron, H. 1972. The effects of age and time of harvest on the productivity of irrigated sugarcane. Proc. S. Afr. Sug. Technol. Ass. Congress 46, 142-150.

Rossler, R.L. 2014. Water Stress Effects on the Growth, Development and Yield of Sugarcane. University of Pretoria, Pretoria, pp. p 124 (M.Sc. Agric. Dissertation). 
Ryker, T.C. and Edgerton, C.W. 1931. Studies on sugarcane roots. Louis. Agric. Exp. Sta. Bull. 223: 36 .

Sartoris, G.B. 1929. Low temperature injury to stored sugar cane J. Agric. Res. 38: 195-203.

Singels, A., Jones, M., van den Berg, M. 2008. DSSAT v4.5 Canegro Sugarcane Plant Module: Scientific documentation. SASRI, Mount Edgecombe, South Africa. pp 34.

Sinclair, T.R., Gilbert, R.A., Perdomo, R.E., Shine, J.M., Jr. Powell, G. and Montes, G. 2004. Sugarcane leaf area development under field conditions in Florida, USA. Field Crops Research 88: 171-178

Singels, A., Kennedy, A.J. and Bezuidenhout, C.N. 2000. The effect of water stress on sugarcane biomass accumulation and partitioning. Proc S Afr Sug Technol Ass 74: 169-172.

Singels, A. and Bezuidenhout, C.N. 2002. A new method of simulating dry matter partitioning in the Canegro sugarcane model. Field Crops Research 78: 151 - 164.

Singels, A., Jones, M.R., Marin, F., Ruane, A.C. and Thorburn, P. 2014. Predicting climate change impacts on sugarcane production at sites in Australia, Brazil and South Africa using the Canegro model. Sugar Tech 16(4): 347-355 (also published in Int. Sugar J. 115: 874881).

Singels, A., Kennedy, A.J., and Bezuidenhout, C.N. 1998. Irricane: a simple computerised irrigation scheduling method for sugarcane. Proc. S. Afr. Sug. Technol. Ass. 72, 117-122.

Singels, A., Donaldson, R.A. and Smit, M.A. 2005a. Improving biomass production and partitioning in sugarcane: theory and practice. Field Crops Res. 92: 291-303. 
Singels, A., Smit, M.A., and Redshaw, K.A. 2005b. The effect of crop start date, crop class and cultivar on sugarcane canopy development and radiation interception. Field Crops Research 92: 249-260.

Singels, A., Van Den Berg, M., Smit, M.A., Jones, M.R. and Van Antwerpen, R. 2010. Modelling water uptake, growth and sucrose accumulation of sugarcane subjected to water stress. Field Crops Research 117: 59-69.

Singels, A., Jones, M.R., Porter, C., Smit, M.A. Kingston, G., Marin, F. Chinorumba, S., Jintrawet, A. Suguitani, C., van den Berg, M., Saville, G. 2010. The DSSAT4.5 Canegro model: A useful decision support tool for research and management of sugarcane production. Proc. Int. Soc. Sugar Cane Technol. 27.

Slabbers, P.J. 1979. Practical prediction of actual evapotranspiration. Irrig. Sci. 1: 185-196.

Smit, M.A. and Singels, A. 2006. The response of sugarcane canopy development to water stress. Field Crops Res. 98: 91-97.

Smit, M.A. and Singels, A. 2007. Quantifying the effects of environment and genotype on stalk elongation rate in sugarcane. Proceedings International Society of Sugar Cane Technologists 26, 568-572.

Smit, M.A., 2010. Characterising the factors that affect germination and emergence in sugarcane. Proc S Afr Sug Technol Ass 83: 230 - 234.

Steduto, P., Hsiao, T.C., and Raes, D. 2009. AquaCrop: The FAO Crop Model to Simulate Yield Response to Water: I: Concepts and Underlying Principles. Agronomy Journal, 101, 426-437.

Stokes, C. J., Inman-Bamber, N. G., Everingham, Y. L., and Sexton, J. 2016. Measuring and modelling CO2 effects on sugarcane. Environmental Modelling \& Software 78: 68-78. 
Supit, I., Hooijer, A.A., van Diepen, C.A. (Eds.), 1994. System Description of the WOFOST 6.0 Crop Simulation Model Implemented in CGMS. Volume 1: Theory and Algorithms. Joint Research Centre of the European Commission, Luxembourg, Office for Official Publications of the European Communities, EUR 15956, p. 146.

Thornley, J.H.M. 1976. Mathematical models in plant physiology. Academic Press (Inc.), London.

Thornley, J.H.M. and Johnson, I.R. 1990. Plant and Crop Modelling. Oxford University Press, Oxford, UK, p. 669.

Thorburn, P.J. Biggs, J.S., Attard, S.J., Kemei, J. 2011. Environmental impacts of irrigated sugarcane production: nitrogen lost through runoff and leaching. Ecosystems \& Environment 144: $1-12$.

Thorburn P, Biggs J, Jones MR, Singels A, Marin F, Martine J-F, Chinorumba S, Viator R and Nunez O. 2014. Evaluation of the APSIM-Sugar model for simulating climate change impacts at sites in seven countries. Proc. S. Afr. Sug. Technol. Ass. 87: 318-322

Thornley, J.H.M. 2011. Plant growth and respiration re-visited: maintenance respiration defined - it is an emergent property of, not a separate process within, the system - and why the respiration: photosynthesis ratio is conservative. Annals of Botany 108: 1365-1380.

Van Heerden, P.D.R., Donaldson, R.A., Watt, D.A. and Singels, A. 2010. Biomass accumulation in sugarcane: Unravelling the factors underpinning reduced growth phenomena. Journal of Exp. Bot. 61: 2877-2887

Van der Merwe, M.J. and Botha, F.C. 2014. Respiration as a competitive sink for sucrose accumulation in sugarcane culm: Perspective and open questions. In: Physiology, 
biochemistry and functional biology of sugarcane. (Ed: P.H. Moore and F. C. Botha). 541571. World in Agriculture Series. Wiley-Blackwell. ISBN 978-1-118-77138-9.

Van Dillewijn C. 1952. Botany of sugarcane. Chronica Botanics Co., Waltham, M.A. USA, p.: 371.

Malan, C., Baartman, J., Berner, J.M., Patton, A., Hoffman, N., Singels, A. and van Heerden, P.D.R. 2017. Effects of elevated $\mathrm{CO}_{2}$ on stomatal conductance, biomass partitioning and yield of sugarcane grown in absence of soil water deficit. 2nd Agriculture and Climate Change Congress, 26-28 March 2017, Sitges, Spain. (poster paper)

Vu, J.C.V., Allen, L.H. Jr., and Gesch, R.W. 2006. Up-regulation of photosynthesis and sucrose metabolism enzymes in young expanding leaves of sugarcane under elevated growth CO2. Plant Science 171: 123-131.

Ward, J.K., Tissue, D.T., Thomas, R.B. and Strain, B.R. 1999. Comparative responses of model $\mathrm{C} 3$ and $\mathrm{C} 4$ plants to drought in low and elevated $\mathrm{CO}_{2}$. Global Change Biology 5: 857867

Webster, A.J., Thorburn, P.J., Roebeling, P.C., Horan, H.L., and Biggs, J.S. 2009. The expected impact of climate change on nitrogen losses from wet tropical sugarcane production in the Great Barrier Reef region. Marine Freshwater Res. 60, 1159-1164.

Zhou, M., Singels, A. and Savage, M.J. 2003. Physiological parameters for modelling differences in canopy development between sugarcane cultivars. Proc S Afr Sug Technol Ass $77: 610-621$. 